\title{
Global dominance of tectonics over climate in shaping river longitudinal profiles
}

Hansjörg Seybold ${ }^{1 *}$, Wouter R. Berghuijs ${ }^{1 *}$, Jeff P. Prancevic ${ }^{2,3}$, James W. Kirchner ${ }^{1,3,4}$

${ }^{1}$ Department of Environmental Systems Science, ETH Zurich, 8092 Zürich, Switzerland

${ }^{2}$ Department of Geography, Planning and Environment, Concordia University Montréal, Québec, Canada.

${ }^{3}$ Department of Earth and Planetary Science, University of California, Berkeley, California 94720, USA

${ }^{4}$ Swiss Federal Research Institute WSL, Birmensdorf CH-8903, Switzerland

*both authors contributed equally to this work

Corresponding author: Wouter R. Berghuijs (wouter.berghuijs@usys.ethz.ch) 


\begin{abstract}
River networks are striking features engraved into Earth's surface, shaped by uplift and erosion under the joint influence of climate and tectonics. How a river descends along its course - its longitudinal profile - varies greatly from one basin to the next, reflecting the interplay between uplift and erosional processes. It has recently been argued that climatic aridity should be a firstorder control on river profile concavity, but the importance of climate relative to other factors has not been tested at global scale. Here we show, using recent global datasets of river profiles and tectonic activity, that tectonics is much more strongly expressed than climate in global patterns in river profile concavity. River profiles tend to be more strongly concave in tectonically active regions along plate boundaries, reflecting tectonically induced spatial variations in uplift rates. Rank correlations between river profile concavity and global tectonic proxies (basin slope and two indices of seismic risk) are much stronger than those between river concavity and precipitation, potential evapotranspiration, or aridity. These results show that tectonics, and not climate, exerts first-order control on the shape of river longitudinal profiles globally.
\end{abstract}

\title{
Introduction
}

Rivers dynamically shape Earth's landscapes [Twidale, 2004; Willet et al., 2014], ecosystems [Palmer et al., 2009], and human society [Mård et al., 2018]. River networks vary greatly across the globe, exhibiting diverse planform and elevation patterns [Van den Berg, 1995; Seybold et al., 2017; Chen et al., 2019]. A river can be characterized by its longitudinal profile, which quantifies how its elevation declines - often steeply at first, and then more gradually - as it flows from its source to its mouth [Gilbert, 1877; Shulits, 1941; Culling, 1956; Whipple \& Tucker, 1999]. Broadly, river longitudinal profiles are shaped by the interplay between tectonic forces, which drive spatial patterns of uplift and subsidence, and the processes of fluvial erosion and deposition, which modify the topographic relief created by tectonics [Gilbert, 1877; Sklar \& Dietrich 1998; Whittaker et al., 2008; Ferrier et al., 2013; Kirby \& Whipple, 2012; Yang et al., 2015].

River longitudinal profiles are typically concave (i.e., steeper in the headwaters than further downstream), reflecting the feedback between tectonics and river morphodynamics. Where tectonic uplift steepens the landscape, the steeper rivers that result will be more erosive, gradually counteracting the increased uplift. The erosivity of rivers also depends on the amount of streamflow available to move sediment and erode rock. Because headwaters have smaller streamflows, they must be steep for incision to keep pace with uplift, but further downstream, larger streamflows can accomplish the same incision at a gentler river gradient. In steady state, this relationship between erosivity and streamflow results in the characteristic concave-up shape of river longitudinal profiles [Gilbert, 1877; Whipple \& Tucker, 1999; Chen et al., 2019]. The same relationship could potentially lead to straighter or convex river profiles where streamflow declines downstream, as sometimes occurs in arid regions [Chen et al., 2019].

Local and regional investigations [e.g., Demoulin, 1998; Pritchard et al., 2009; Kirby \& Whipple, 2012; Yang et al., 2015; Gallen \& Wegmann, 2017] have shown how tectonics can strongly influence river profile concavity, particularly in tectonically active regions. By contrast, the recent global analysis of Chen et al. [2019] reported that climatic aridity is a first-order control on river concavity, with arid regions having straighter river profiles. However, Chen et al.'s underlying data reveal tremendous scatter in river concavity that is not explained by aridity, 
and they did not quantify the effects of other potential controls on river longitudinal profiles. Thus we presently lack a quantitative understanding of the relative importance of different factors controlling river longitudinal profiles globally.

Here we compare Chen et al.'s global dataset of 333,502 river longitudinal profiles [Chen et al., 2019] with global datasets of climate, river slope, and seismic activity [Giardini et al., 1999; Trabucco \& Zomer, 2009; Fick \& Hijmans, 2017; Pagani et al., 2020] to test the relative importance of tectonics versus climate as global controls on river profile concavity. Following Chen et al. [2019], we characterize river longitudinal profiles by their Normalized Concavity Index (NCI), a dimensionless measure of a river profile's median deviation from a straight line (see Methods, and Fig. S1), thus indicating whether it is concave $(-0.5<\mathrm{NCI}<0$, decreasing slope downstream), straight $(\mathrm{NCI}=0)$, or convex $(0<\mathrm{NCI}<0.5$, increasing slope downstream). $\mathrm{NCI}$ depends only on how slope varies downstream, not on the average slope of the river profile or its total relief. By testing how river profile concavity correlates with both climatic and tectonic indices, we reveal a clear dominance of tectonics over climate in shaping river longitudinal profiles globally.

\section{Tectonic controls on river profiles}

Globally, most river segments are concave-up, with channel slopes decreasing downstream (median NCI $=-0.0755$ ) [Chen et al. 2019]. NCI values vary regionally (Fig. 1), indicating a tendency toward more concave river profiles in the Rocky Mountains, Andes, Himalaya, and Tibetan Plateau, along the Pacific Ring of Fire and the East African rift valley, and in mountains stretching from the Alps to the Zagros mountains of Iran. These spatial patterns are more clearly visible in Fig. 1 than in Chen et al.'s previous global analysis [Chen et al., 2019] because Fig. 1 aggregates NCI values over mesoscale river basins (see Methods), averaging over the profile-toprofile variability that would otherwise obscure most regional patterns.

Many zones of strongly concave river profiles (light colors in Fig. 1) are associated with tectonic plate boundaries (black lines in Fig. 1). These include the subduction zones, transform faults, and rifts of the Pacific Ring of Fire and their associated mountain ranges; the convergent boundary between the Eurasian plate and the African, Arabian and Indian plates, which is responsible for the uplift of the Alpine-Himalayan orogenic belt and the Tibetan plateau; the East African Rift; the rifts and transform faults bounding the Yangtze, Amur and Okhotsk plates; the convergent boundaries between the South American plate and the Altiplano and North Andes plates; and the transform faults bounding the Caribbean plate. 


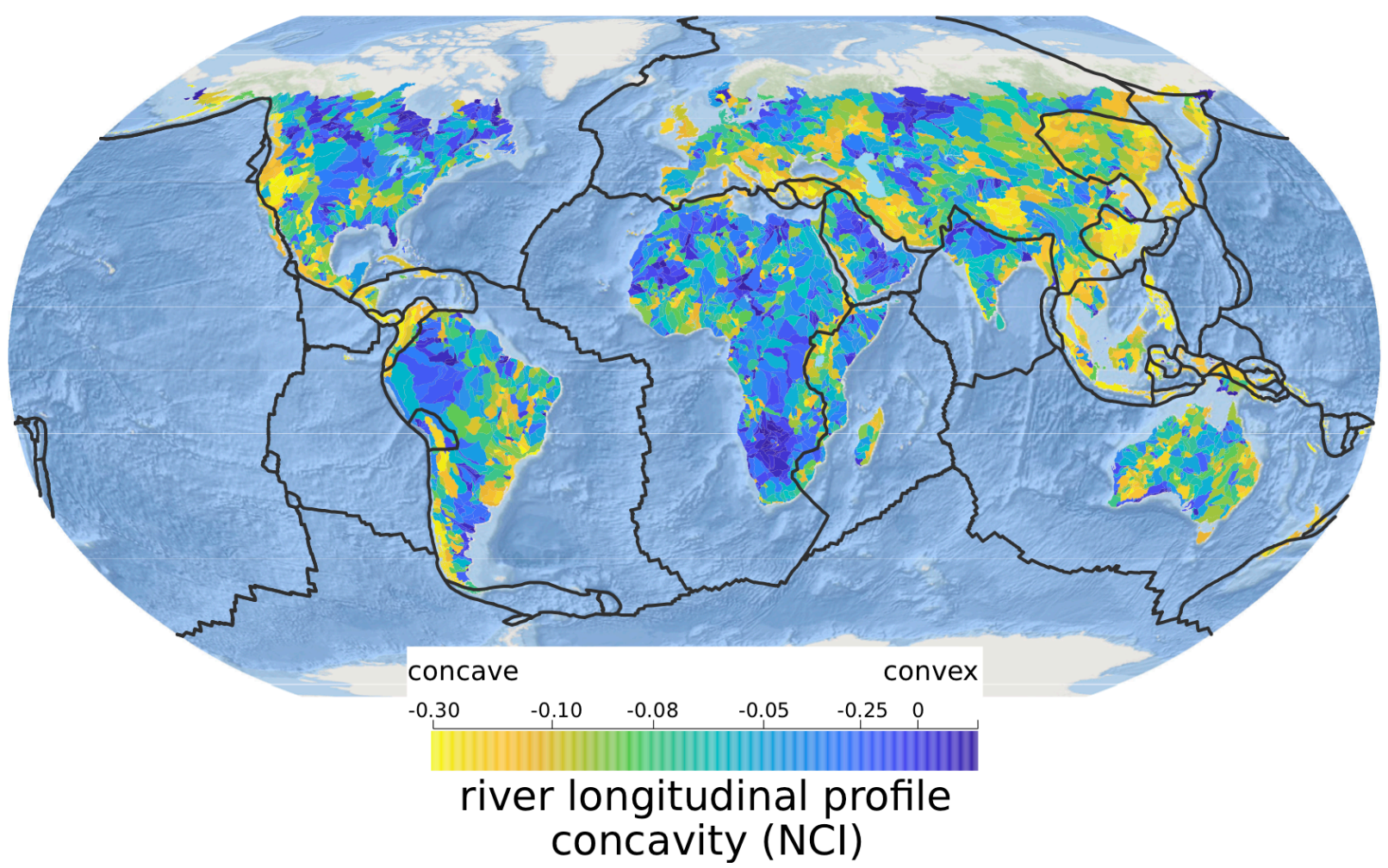

Fig. 1| Global distributions of basin-averaged river longitudinal profile concavity (NCI) and tectonic plate boundaries (black lines). River profiles tend to be strongly concave-up in tectonically active regions along plate boundaries, and straighter in tectonically passive regions far from plate boundaries.

The spatial association of plate boundaries and river profile concavity suggests a strong tectonic control on river profiles. We quantitatively explore this possibility using three proxy measures of tectonic activity: mean river profile slope and two metrics of seismic risk (from the Global Earthquake Model [Pagani et al., 2020] and the Global Seismic Hazard Assessment Program [Giardini et al., 1999]). The global patterns in these tectonic proxies (Fig. 2a-c) are clearly associated with the plate boundaries, and broadly correspond to the global pattern in river concavity (Fig. 1). Exceptions can be found, however; in Ireland, Uruguay, south-eastern China, south-eastern Brazil, and southwest Australia, for example, areas of low seismic risk are associated with strong river profile concavity. Nonetheless, river profile concavity correlates strongly with all three proxies for tectonic activity (mean river slope and two measures of earthquake risk), with Spearman rank correlations of $\rho=-0.31$ to -0.37 (Figs. 3a-c). 

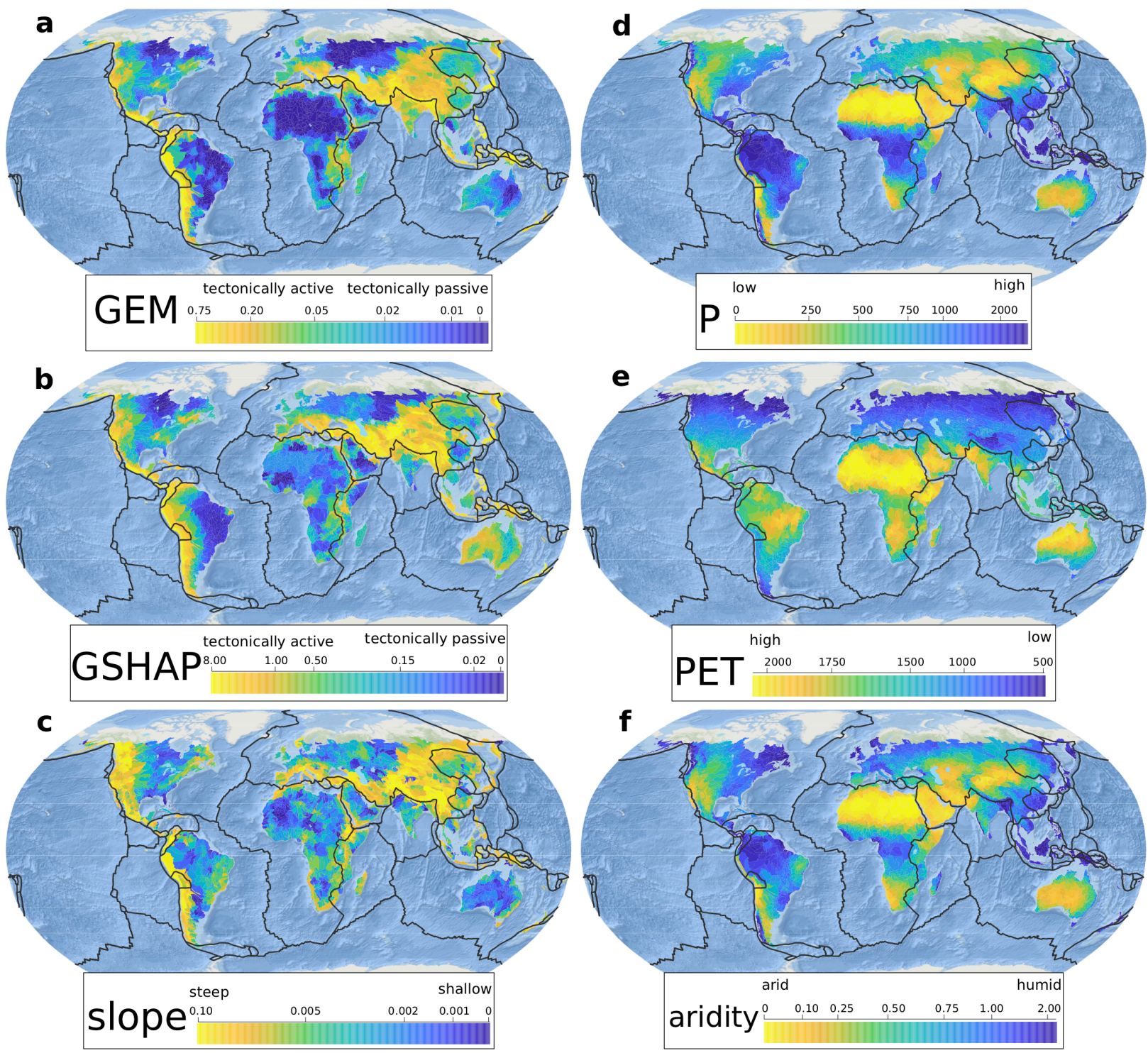

Fig. 2| Global distributions of basin-averaged climate characteristics and proxies of tectonic activity. The global patterns of proxy measures of tectonic activity - seismic risk from the Global Earthquake Model index (GEM, a), the Global Seismic Hazard Assessment Program index (GSHAP, b), and mean river profile gradient (slope, c) - all broadly correspond to the tectonic plate boundaries, and to the global pattern in river concavity (Fig. 1). The global patterns of three climatic indices - precipitation $(\mathrm{P}, \mathbf{d})$, potential evapotranspiration $(\mathrm{PET}, \mathbf{e})$, and aridity $(\mathrm{P} / \mathrm{PET}, \mathbf{f})$ - are not clearly associated with either the tectonic plate boundaries or the global pattern in river profile concavity.

\section{Climatic controls on river profiles}

We also tested the association of river profile concavity with three climatic indices: mean precipitation P [Fick \& Hijmans, 2017], mean potential evapotranspiration PET [Trabucco \& Zomer, 2009], and climatic aridity (defined as P/PET; [Chen et al., 2019; Trabucco \& Zomer, 2009]). All three climatic indices show distinct regional variations (Figs. 2d-f), but only weak spatial association with global patterns of river profile concavity (Fig. 1). River profile concavity (NCI) is weakly correlated with climate aridity, precipitation, and potential evapotranspiration, 
with Spearman rank correlations of $\rho=-0.13$ to 0.08 (Figs. 3d-f). These correlations are statistically significant because the sample size is large, but they are much weaker than the correlations between NCI and any of our indices of tectonic activity. Thus they do not support the recent suggestion that climate, and specifically climatic aridity, should be a first-order control on global patterns of river profile concavity [Chen et al., 2019].
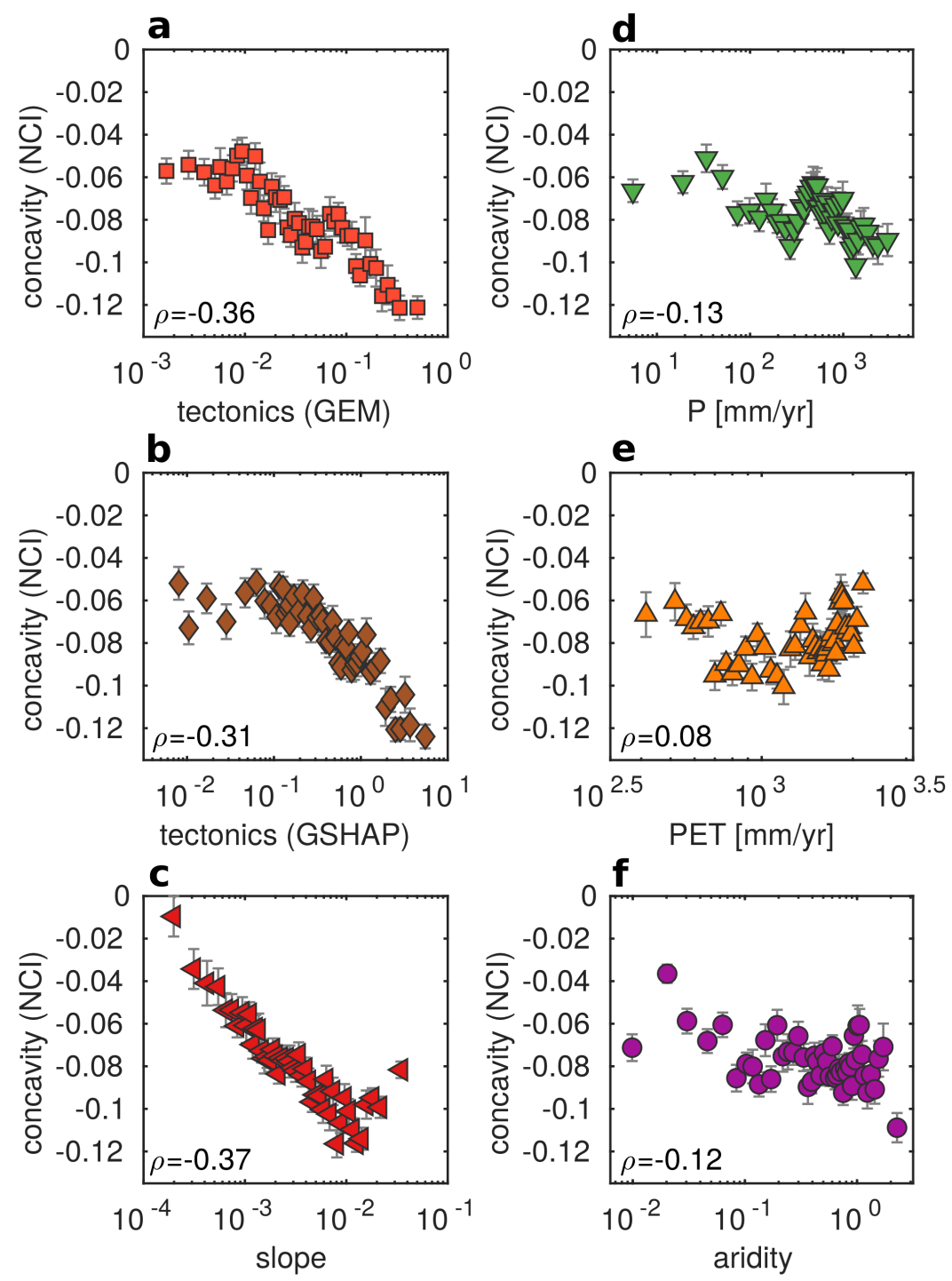

Fig. 3| Correlations between river profile concavity and tectonic and climatic indices. Basinaveraged and binned river profile concavity index ( $\mathrm{NCI}$ ) is strongly correlated with three indices of tectonic activity: the Global Earthquake Model index (GEM, a), the Global Seismic Hazard Assessment Program index (GSHAP, b), and mean river profile gradient (slope, $\mathbf{c}$ ). NCI is only weakly correlated with three climatic indices: precipitation $(\mathrm{P}, \mathbf{d})$, potential evapotranspiration (PET, e), and aridity index (P/PET, f). Spearman rank correlations $(\rho)$ are shown for the unbinned, basin-averaged values. The rank correlations of the plotted (i.e., binned) points are visibly stronger, but vary depending on the details of the binning. A counterpart figure showing the same data, but without averaging over basins, is shown in Supplementary Fig. S2. 


\section{Discussion}

The association between tectonic activity and increased river profile concavity (more negative values of NCI) can be understood through a simple conceptual model of long-term uplift and river incision (see also Supplementary Information S3). Tectonic activity in whatever form (e.g., continental collision, rifting, or subduction and arc formation) causes spatial variations in longterm uplift rates. To first order, higher uplift rates are expressed over geologic time as higher and steeper topography. And while relationships between uplift and elevation can vary for individual basins, we propose that the highest terrain, where the headwaters of river systems are found, will tend to correspond to higher long-term uplift rates than the adjacent lowlands. These contrasts in long-term uplift rates will usually be greater where tectonic activity is stronger. (Note that this model does not assert that the fastest rates of uplift coincidentally occur where the river headwaters are. Instead it asserts the opposite: that rivers' headwaters will by definition be found high in their basins, where long-term uplift rates have tended to be faster.)

The large-scale topography will evolve according to the balance between uplift and river incision. Because steeper rivers incise faster, all else equal, landscapes whose uplift rates have been higher over the long term will usually have evolved to be both higher and steeper than adjacent landscapes with lower long-term uplift rates. Therefore regions with greater contrasts in uplift rates should also exhibit greater contrasts between the gradients of their headwater streams and their lowland rivers, and thus greater longitudinal profile concavity (see Supplementary Information S3).

This simple model excludes many other potentially important factors, including climate [Roe et al., 2002; Chen et al., 2019], sediment sorting and breakdown [Blom et al., 2016], and spatial variations in precipitation rates [Willett, 1999], and bedrock erodibility [Duvall et al., 2004]. Some of these factors may contribute to the apparent relationship between tectonics and concavity. For example, in addition to having higher uplift rates, high topography tends to be underlain by stronger and denser rock [Braun et al., 2018], and to produce coarser sediment [e.g., Sklar et al., 2017], both of which can locally steepen headwater channels and increase concavity. However, all of these factors also vary independently of tectonics, and likely account for some of the scatter in the relationship between tectonics and concavity (Fig. 3).

Although geomorphic theory and regional empirical studies both suggest that climatic influences should be reflected in longitudinal profile concavity [Roe et al., 2002; Tucker, 2004; Wobus et al., 2010; Chen et al., 2019], the data presented here demonstrate that across the globe as a whole, the profile concavity index NCI correlates only weakly with climate, and much more strongly with tectonic activity. While the connections between tectonics and river profiles have been examined in numerous local and regional studies [Demoulin, 1998; Pritchard et al., 2009; Kirby \& Whipple, 2012; Yang et al., 2015; Gallen \& Wegmann, 2017], by merging recent global datasets [Giardini et al., 1999; Pagani et al., 2020, Trabucco \& Zomer, 2009; Fick \& Hijmans, 2017; Chen et al., 2019], our analysis reveals a previously unrecognized global pattern, namely that tectonic activity is generally associated with greater river profile concavity. This relationship is not only supported by our global data synthesis, but also by a simple model of long-term uplift and river incision (see Supplementary Information S3). Together our results indicate the dominance of tectonics over climate in shaping river longitudinal profiles globally, implying that river profile concavities have probably remained largely unaffected by changes in climate over 
geological time, instead reflecting spatial patterns in the slow dance of Earth's crust. We close by noting that a substantial fraction of the variance in river profile concavity remains unexplained by either the tectonic or climatic variables considered here. Some of this unexplained variance is measurement noise, but probably not all. Thus it is likely that global patterns in river profile concavity contain clues to other explanatory factors that are yet to be discovered. 


\section{Methods}

River longitudinal profiles. We used Chen et al.'s [2019] recent global compilation of longitudinal profiles for 333,502 river segments (with an average length of $30 \mathrm{~km}$ ) extracted from NASA's 30-m-resolution Shuttle Radar Topography Mission Digital Elevation Model (SRTM-DEM), and their associated values of the Normalized Concavity Index (NCI). The NCI is defined as the median value of a river profile's vertical deviation from a straight line connecting its endpoints, normalized by its total topographic relief,

$$
\mathrm{NCI}=\operatorname{median}\left(\frac{z_{S}-z_{L}}{z_{\max }-z_{\min }}\right)
$$

where $z_{S}$ and $z_{L}$ are the elevations of the river and the straight line at each point $L$ along the profile, and $z_{\max }$ and $z_{\min }$ are its most upstream and downstream elevations [Chen et al., 2019; see also Supplementary Fig. S1]. In the usual case that channel gradients decrease downstream (concave profiles), NCI will be negative; where channel gradients become steeper downstream (convex profiles), NCI will be positive. NCI values are not shown for latitudes above $60^{\circ} \mathrm{N}$ and $56^{\circ} \mathrm{S}$, where SRTM topography is unavailable.

Tectonic proxies. We used three proxies for tectonic activity. 1) The Global Earthquake Model's Global Seismic Hazard Map [GEM, version 2018.1; Pagani et al., 2020] depicts, at 4-km resolution, the peak ground acceleration that has a $10 \%$ probability of being exceeded in 50 years. This map collates national and regional probabilistic seismic hazard information into a consistent global framework; technical details are available at https://hazard.openquake.org/gem. 2) The Global Seismic Hazard Assessment Program's global seismic activity map [GSHAP; Giardini et al., 1999] quantifies the peak ground acceleration (PGA) predicted to occur with a 475-year return period. These PGA predictions are based on catalogs of observed earthquakes and active faults, as well as models of seismic wave propagation. 3) Mean river profile gradients are calculated using the start- and endpoint elevations, and the total lenghth, of each of Chen et al.'s river profiles [Chen et al., 2019].

Climate data. We used three climate indices with global coverage at 4-km resolution: precipitation [WorldClim v. 1.4; Fick \& Hijmans, 2017], potential evapotranspiration [Trabucco and Zomer, 2009], and climatic aridity [Chen et al., 2019]. Climate aridity is defined as the ratio of mean precipitation to mean potential evapotranspiration; thus higher aridity values reflect more humid areas while lower values reflect drier areas.

Aggregation to profiles and basins. We extracted climatic and tectonic variables for each pixel in each river profile. These values are then averaged to yield mean values for each profile. We assigned each river profile to a level-5 HydroSHED basin based on the location of its midpoint. We then averaged the climatic and tectonic indices, as well as NCI, for all profiles within each HydroSHED basin. 


\section{Acknowledgments}

All data used in this study are available via the cited sources. We thank the Global Earthquake Model Foundation for providing the The Global Earthquake Model's Global Seismic Hazard

Map. J.P.P. is supported by the Swiss National Science Foundation (project \#: P400P2_183929).

\section{Author contributions}

H.J.S., J.P.P., J.W.K., and W.R.B. conceived the idea and designed the study. H.J.S. analyzed the data. J.W.K. led the analysis in the Supplementary Information, with contributions from W.R.B. and H.J.S. All authors contributed to interpreting the results. W.R.B. and J.W.K. led the writing, with contributions from all authors.

\section{Competing interests}

The authors declare no competing interests. 


\section{References}

Blom, A., Viparelli, E., \& Chavarrías, V. (2016). The graded alluvial river: Profile concavity and downstream fining. Geophysical Research Letters, 43, 6285-62.

Braun, J., Simon-Labric, T., Murray, K. E., \& Reiners, P. W. (2014). Topographic relief driven by variations in surface rock density. Nature Geoscience, 7(7), 534-540.

Chen, S. A., Michaelides, K., Grieve, S. W., \& Singer, M. B. (2019). Aridity is expressed in river topography globally. Nature, 573, 573-577.

Culling, E. W. H. (1956). Longitudinal profiles of the Chiltern streams. Proceedings of the Geologists' Association, 67(3-4), 314-IN17.

Demoulin, A. (1998). Testing the tectonic significance of some parameters of longitudinal river profiles: the case of the Ardenne (Belgium, NW Europe). Geomorphology, 24(2-3), 189-208.

Duvall, A., Kirby, E., \& Burbank, D. (2004). Tectonic and lithologic controls on bedrock channel profiles and processes in coastal California. Journal of Geophysical Research: Earth Surface, 109, F03002.

Ferrier, K. L., Huppert, K. L. \& Perron, J. T. (2013). Climatic control of bedrock river incision. Nature, 496, 206-209.

Fick, S. E., \& Hijmans, R. J. (2017). WorldClim 2: new 1-km spatial resolution climate surfaces for global land areas. International Journal of Climatology, 37(12), 4302-4315.

Gallen, S. F., \& Wegmann, K. W. (2017). River profile response to normal fault growth and linkage: An example from the Hellenic forearc of south-central Crete, Greece. Earth Surface Dynamics, 5(1), 161-186.

Giardini, D., Grünthal, G., Shedlock, K. M., \& Zhang, P. (1999). The GSHAP global seismic hazard map. Annals of Geophysics, 42(6), 1225-1230.

Gilbert, G. K. (1877). Report on the Geology of the Henry Mountains, p. 160, U.S. Gov. Print. Off., Washington, D. C.

Kirby, E., \& Whipple, K. X. (2012). Expression of active tectonics in erosional landscapes. Journal of Structural Geology, 44, 54-75.

Mård, J., Di Baldassarre, G., \& Mazzoleni, M. (2018). Nighttime light data reveal how flood protection shapes human proximity to rivers. Science Advances, 4(8), eaar5779.

Pagani, M., Garcia-Pelaez, J., Gee, R., Johnson, K., Poggi, V., Silva, V., Simionato, M., Styron, R., Vigano, D., Danciu, L., Monelli, D., \& G. Weatherill (2020). The 2018 version of the Global Earthquake Model: Hazard component. Earthquake Spectra, accepted.

Palmer, M. A., Lettenmaier, D. P., Poff, N. L., Postel, S. L., Richter, B., \& Warner, R. (2009). Climate change and river ecosystems: protection and adaptation options. Environmental Management, 44(6), 1053-1068.

Pritchard, D., Roberts, G. G., White, N. J., \& Richardson, C. N. (2009). Uplift histories from river profiles. Geophysical Research Letters, 36, L24301.

Roe, G. H., Montgomery, D. R., \& Hallet, B. (2002). Effects of orographic precipitation variations on the concavity of steady-state river profiles. Geology, 30(2), 143-146.

Seybold, H., Rothman, D. H., \& Kirchner, J. W. (2017). Climate's watermark in the geometry of stream networks. Geophysical Research Letters, 44(5), 2272-2280.

Shulits, S. (1941). Rational equation of riverbed profile. Transactions of the American Geophysical Union, 22, 622-630.

Sklar, L., \& Dietrich, W. E. (1998). River Longitudinal Profiles and Bedrock Incision Models: Stream Power and the Influence of Sediment Supply. Rivers Over Rock: Fluvial Processes in Bedrock Channels, 107, 237-260. 
Sklar, L. S., Riebe, C. S., Marshall, J. A., Genetti, J., Leclere, S., Lukens, C. L., \& Merces, V. (2017). The problem of predicting the size distribution of sediment supplied by hillslopes to rivers. Geomorphology, 277, 31-49.

Trabucco, A. \& Zomer, R. J. (2009). Global Aridity and PET Database http://www.cgiarcsi.org/data/global-aridity-and-pet-database (CGIAR Consortium for Spatial Information, 2009). Tucker, G. E. (2004). Drainage basin sensitivity to tectonic and climatic forcing: Implications of a stochastic model for the role of entrainment and erosion thresholds. Earth Surface Processes and Landforms, 29(2), 185-205.

Twidale, C. R. (2004). River patterns and their meaning. Earth-Science Reviews, 67(3-4), 159218.

Van den Berg, J. H. (1995). Prediction of alluvial channel pattern of perennial rivers. Geomorphology, 12(4), 259-279.

Whipple, K.X, \& Tucker, G.E. (1999). Dynamics of the stream-power river incision model: Implications for height limits of mountain ranges, landscape response time scales, and research needs. Journal of Geophysical Research, 104(B8), 17661- 17674.

Whipple, K. X. (2004). Bedrock rivers and the geomorphology of active orogens. Annual Review of Earth and Planetary Sciences, 32, 151-185.

Whittaker, A. C., Attal, M., Cowie, P. A., Tucker, G. E., \& Roberts, G. (2008). Decoding temporal and spatial patterns of fault uplift using transient river long profiles. Geomorphology, 100(3-4), 506-526.

Willett, S. D. (1999). Orogeny and orography: The effects of erosion on the structure of mountain belts. Journal of Geophysical Research: Solid Earth, 104(B12), 28957-28981. Willett, S. D., McCoy, S. W., Perron, J. T., Goren, L., \& Chen, C. Y. (2014). Dynamic reorganization of river basins. Science, 343(6175), 1248765.

Wobus, C. W., Tucker, G. E., \& Anderson, R. S. (2010). Does climate change create distinctive patterns of landscape incision?. Journal of Geophysical Research: Earth Surface, 115, F04008. Yang, R., Willett, S. D., \& Goren, L. (2015). In situ low-relief landscape formation as a result of river network disruption. Nature, 520(7548), 526-529. 